\title{
An Analysis of the Implementation of Shari'ah Principles in the Management of Takaful
}

\author{
Maryam Dikko ${ }^{*}{ }^{1}$, Abdullah B Hj Abdul Ghani ${ }^{2}$
}

\begin{abstract}
This study was conducted to establish the level of knowledge of the management of takaful providers in Nigeria of Islamic financial principles relating to takaful and to determine whether the management operations of the takaful providers are in complete compliance with Islamic financial principles relating to their chosen takaful model. Using qualitative research techniques, the study discovered that the majority of persons chosen to run takaful units were inadequately educated concerning takaful. It was also discovered that some takaful providers had issues with shari'ah compliance to conditions for the validity in Islamic law of their chosen mode of financing. The paper concluded with recommendations to ensure persons dealing in the provision of takaful are adequately educated and mechanisms put in place to regulate takaful operations particularly those pertaining to modes of financing
\end{abstract}

Keywords- Takaful principles, Islamic modes of financing, mudarabah financing, takaful models, shari'ah compliance.

\section{Introduction}

Takaful is "A type of Islamic insurance, where members contribute money into a pooling system in order to guarantee each other against loss or damage. The term derived from the Arabic root word kafala (which means guarantee), refers to a system of insurance which provides risk protection within Islamic parameters (Bekkin, 2007; Usman, 2000). The basic principle which provides the foundation for takaful insurance is risk protection based on mutual help and brotherhood where it is the responsibility of individuals facing the same type of risk to cooperate and protect each other (Ahmed \& Ahmed. nd; Maysami \& Williakims, 2006). Thus it is "a scheme that is based on brotherhood, solidarity and mutual assistance which provides for mutual financial aid and assistance to the participants in case of need whereby the participants mutually agree to contribute for that purpose (1984 Malaysian Takaful Act).

Maryam Dikko (Corresponding Author)

Othman Yeop Abdullah Graduate School of Business,

Universiti Utara Malaysia

Prof. Abdullah B. Hj Abdul Ghani

College of Business, Universiti Utara,Malaysia
This system of contribution itself is based on a concept referred to as the principle of 'Tabarru' (donation/charity). Therefore, while under conventional insurance risk protection is provided by the insurance company in exchange for premium payments, in takaful, the insured persons provide this protection for each other as the risk is distributed and managed based on taawun (solidarity and mutual assistance). Furthermore, with conventional insurance, all premium payments and the risk fund from which claims are satisfied belongs to the company with the company aiming to make profits by paying out, as claims, less than it collects. (Rejda, 2011). With takaful, on the other hand, the risk pool belongs to the contributors (usually referred to as takaful participants) who hand it over to a manager (referred to as the takaful operator) to oversee contributions and claims payments. The common practice is to invest the fund and the takaful operator is paid by for its services via an arrangement with the participants (operating model) using either one of the various Islamic modes of financing. This paper presents the results of a study into the Nigerian takaful practice and management against the backdrop of Islamic financial laws.

In Nigeria, takaful services are provided by three conventional insurers. Two of which is do so via window operations while the third as a subsidiary of the parent company. For the purpose of this research, three research questions were raised:

i. What is the extent of the knowledge of the basic principles underlying takaful of the heads of takaful units of the companies?

ii. What is the extent of the knowledge of Islamic modes of financing of the heads of takaful units of the companies?

iii. To what extent do the companies implement and follow the guidelines and the conditions relating to their choice of mode of financing in the takaful model?

These questions are hoped to achieve the research objectives

i. To establish the extent of the knowledge of the basic principles underlying takaful of the heads of takaful units of the companies?

ii. To determine the level of understanding and exposure of heads of takaful units of the takaful providers to the laws and regulations pertaining to the mode of financing chosen by their company

iii. To determine the extent to which the management of takaful companies in Nigeria comply with Islamic laws and regulations governing their chosen mode of finance for takaful model 
The paper is divided into six sections. After the introduction, an outline is presented of the different modes of financing available in Islamic financial law particularly those relevant to takaful operations. The next section looks at the preferred takaful operating models while explaining how they work to incorporate the modes of financing and the fourth section provides data collection and sampling method used to answer the research questions. The fifth section presents analysis, observations and recommendations.

\section{Modes of Financing, Takaful Operating Models and the Laws Relating Thereto}

This refers to the methods used by Islamic financial intermediaries to generate income for themselves within the confines of ethics, guidelines and prohibitions of Islamic financial law. It indicates a situation where financing is provided for a venture, usually in partnership with others, with the aim of making a profit which profit is usually shared amongst the partners. (Usmani, 1999; Khaf, 2006). The different modes of financing in Islamic law include mudarabah, murabaha, musharakah, ijarah, salam and istisna. Other additional modes of financing include wakala and waqf. However, in relation to takaful, the important modes are mudarabah, wakala and waqf.

A takaful operating model, on the other hand, refers to the arrangement between the takaful operator (TO) and the participants of the takaful fund regarding the system of provision of the takaful operator's remuneration for the service of the management of the takaful fund (Archer et al, 2009; Bakar, 2009; Hussain, 2009; Htay \& Zaharin, 2012; Kwon, 2007). An operating model utilizes one or a combination of the mudarabah, wakalah or waqf modes of financing as contracts of compensation to regulate the arrangement for the payment of the TO (Dusuki \& Abdullah, 2007).

\section{A. Mudarabah}

This is an equity based financing model where one party, referred to as the rabb al mal, provides funds for a business venture while another party, referred to as the mudarib, provides the managerial skill. Profits realized from the venture are then shared according to a predetermined ratio, losses, on the other hand, are borne by the rabb al mal alone while the mudarib takes nothing in the event of the loss (Quraishi, 1947; Sadique, 2009: Gamal, 2006; Obaidullah, 2005; Siddiqui, 2010; Khaf \& Khan, 1992). In effect, the entrepreneur gets a share of the profit in return for his skill and services but gets nothing where he fails to achieve a successful venture.

Before a valid mudarabah can be constituted, the investment fund must be explicitly stated at the inception of the arrangement (Sadique, 2009; Alwosabi, nd), the sharing of profit must be in a predetermined ratio not a percentage of investment (Sadique, 2009; Nadeem, 2010) and the rabb al mal, though not permitted to be involved in the day to day management of the venture, may have a say as to the nature of investments the fund can be involved in (Alwosabi, nd). Furthermore, while profit is shared between the rabb al mal and the mudarib, any loss should be borne by the rabb al mal alone. And finally, at the termination of the arrangement, the rabb al aml is entitled to a return of his capital contribution
When mudarabah is used as an operating model, takaful contributors are considered to be the rabb al mal and the takaful operator is the mudarib with the takaful fund being the capital for investment in shari'ah compliant ventures. Therefore, the takaful operator as manager is expected to provide entrepreneurial skills to manage the fund and in return he becomes entitled to a share of the profits and any surplus from underwriting on a predetermined ratio (Kasim, 2005). Any loss, whether from investments or underwriting, should be absorbed by the participants just as is the rule with mudarabah financing (Htay \& Zaharin, 2012) but the TO may be required to provide a qard hasan to the takaful fund in cases of deficit which will be repaid from future surplus (Abdul Rahim et al, 2007).

In a pure mudarabah model, the TO is responsible for its own management expenses from its share of profits and may not deduct same from the fund. However, a modified mudarabah model has evolved where the TO is also entitled to a share of any underwriting surplus based on a preagreed ratio.

\section{B. Wakala}

The wakalah contract is technically not a model for financing but a service contract where one person, referred to as the wakeel (agent), is employed to perform particular service(s) on behalf of another the muwakkeel (principal) for which the former will be provided remuneration (Ayub, 2007). The wakalah agreement can be used for a multitude of purposes and in conjunction with other modes of financing and in this type of contract, all risks, profits and loss are born by the principal. The remuneration of the wakeel is usually based on the agreement between the principal and the agent which may be a percentage of the amount or it could be an up-front fixed amount irrespective of the funds with the wakeel.

The wakalah takaful model places the TO in the position of an agent employed by the participants to manage the takaful fund in exchange for a fixed agency fee. In this model therefore, the complete ownership of the fund and all benefits accruing to it remains with the participants and in a pure wakalah model, the TO as wakeel merely manages the underwriting activities of the fund and handles the investment of what is left over from the fund after deduction of its wakala fee (which is paid annually) and other expenses attached to the fund. According to Tolefat and Asutay (2013), the TO earns a fee for both services but is not entitled to share in the investment profits (Dusuki \& Abdullah, 2007; Kasim, 2005; Hamid et al, 2010). With the more commonly used model, referred to as the modified wakalah model (Odierno \& Ismail, 2008) or wakalah with incentive fee (Frenz \& Soualhi, 2010) however, in addition to this fee, the TO may also take a share of the surplus of the fund, after claims and expenses, based on a predetermined ratio as performance incentive fee (Dusuki \& Abdullah, 2007; Bhatty, 2007; Zukifli et al, 2012; Tolefat \& Asutay, 2013; Salman \& Htay, 2014).

\section{Waqf (Endowment)}

The Arabic word literally means 'hold', 'confinement' or 'prohibition'. Under Islamic law, it refers to the irrevocable setting aside and designation of particular property (which can exist in perpetuity), either as a religious, charitable or 
pious donation whether real (Cizaka, 2009) or in cash (Chowdhury, Gazali \& Ibrahim, 2011) by way of endowment to be used for the benefit of persons who may not be the owners of the property (Khaf, 1999; Muhammad, Iman, Hamid \& Omar, 2005). A manager(s) is usually appointed to manage the waqf property (safeguard and invest) and is paid a salary for the job as wakeel and the terms of his duties may be general or specific (Ibrahim \& Ibrahim, 2013).

As a takaful model, a waqf fund is initially created by shareholders of the TO for the purpose of providing protection against risk to others and such persons (the takaful participants) become entitled to this protection by applying for membership and paying subscription to the fund. This fund is then handed over to the TO to manage under its choice of mudarabah or wakalah contracts or a combination of the two. However, according to Htay \& Zaharin (2012) unlike other models, any profits from investments belong to the pool and not the participants. Therefore, profits are subsumed back into the waqf takaful fund and cannot be shared amongst the participants as surplus.

\section{Methodology}

This study used semi structured interviews as a qualitative data collection tool. According to Robson (2002), the use of the semi structured interview in one -on -one interviews allows for the collection of data on subject areas which the researcher already has some knowledge using a flexible list of open-ended questions which allows for flexibility within each interview so that optimal information is obtained from participants (Wallace, 1998).

The interviews were conducted with members of the takaful units of each of the two insurance companies providing takaful services via window operations and the third company which does so through a subsidiary. Interviews were also conducted with users of takaful products of each of the providers. In particular, heads of each of the takaful units and participants of each of the providers in three geopolitical zones of the country were interviewed so as to ensure adequate coverage and representation of the entire country. The purpose of obtaining data from both providers and users is to provide triangulation of information by collecting data on the same phenomenon from different sources so as to establish mutual confirmation of data and validation of findings (Berg, 2001). Goetz and LeCompte (1984) view it as a method of strengthening the connections between links in data which allows researchers, particularly in qualitative research, to obtain other perspectives on data apart from their own (Boman, LeCompte \& Goetz, 1996).

To obtain access to takaful participants (also referred to as users), heads of takaful units and members of marketing staff were asked to provide introductions to at least one user of takaful products. Using the snowball sampling technique (Handcock \& Gile, 2011), each user was then asked to provide an introduction to another user. The participants in this study included 10 members of takaful units of which five (5) were from the first Takaful Operator (hereinafter referred to as Company one), (3) from the second (Company two) and two (2) from the third (Company three). Of the 10 users interviewed three (3) were customers of Company one, four (4) were those of Company two and (three) 3 from Company three.

\section{Results, Analysis and Observations}

All of the takaful providers indicated that they used the mudarabah model for takaful operations and this was supported by the policy documents which the researcher was given access to. Therefore, the aim of the research became to ascertain whether the heads of takaful units had adequate working knowledge of the rules governing the mudarabah model. The research also hoped to determine whether the takaful providers were complying with the conditions for the validity of using mudarabah as a mode of financing. This section presents the key findings obtained from the interviews conducted. Following is a discussion of the findings with details that support each finding.

The first major finding was that only four of the heads of takaful units interviewed had a satisfactory understanding of the fundamental principles underlying takaful. The majority of the heads seemed to view takaful as a system of investment or savings based on a profit and loss sharing system. This is evidenced from the excerpts of the interviews conducted;

Head of unit \#1:

"I know takaful works with the Qur'anic principles of no usury (interest). That is we don't talk about interest but about profit"

Head of unit \#2: $\quad$ "My understanding of takaful is that it does not believe in interest".

Head of unit \#3: "the takaful man told us that takaful is a non interest yielding policy, that's the major thing"

Head of unit \#5: "what I understand about takaful is that it is like gathering your money, giving to the beggar..."

The second major finding was that the majority of the unit heads interviewed also had misconceptions about the modalities for the lawful implementation of mudarabah. From the interviews, it became obvious that some believed mudarabah was meant for profit sharing alone and had no idea that the participants, as rabb al mal, would be required to bear any losses that befell the takaful fund while others believed it was a profit and loss sharing system.

Head of unit \#4: "the returns do not come in a usury form. The returns come in a profit or loss sharing form"

Head of unit \#4: "when I asked whether they had ever realized a loss, they told me that whatever they generate every year, they always keep a reserve. When the money from their investment is not forthcoming, they fall back on this reserve so that they keep their customers. Because in Nigeria, no matter their cadre, nobody will like to be associated with loss"

These two findings are probably due to the fact that of the 10 heads interviewed, only three had any formal education in Islamic finance as answers given to questions about 
educational qualifications showed most had foundations in non-related fields ranging from Agriculture to Business Administration. All others had their exposure to Islamic finance principles, particularly takaful principles limited to the odd 'one day training' in takaful products with particular emphasis on how best to sell those products while some had no training at all.

The third major finding was that the management of two of the takaful companies had areas in which they were not in complete compliance with the Islamic financial laws regulating mudarabah as a mode of financing. Lack of compliance ranged from failure to share profits in a predetermined ratio with participants instead being given a fixed percentage of their investment to the allocation of profits to the participants even when investments have not yielded any. In effect, the takaful operator was not only absorbing losses but paying out profits from its own coffers. This was also observed from excerpts of the interviews;

Head of unit \#1: "initially when we started we were giving $10 \%$ of your investment at the end of the year but the economy changed and ...... so presently we give $1 \%$ which is subject to review by the board"

Head of unit \#1:

"from the discussion we have had with management the company is not really making much from takaful. It is running at a loss.... I can tell you that we pay out more than what we

collect...... Nigerian populace

doesn't want to hear about loss"

Takaful user \#3: "when they bring the money the excess that will be on top will not be much. As I did contribution of $\mathrm{N} 20,000$ for a year at the end of it what is on top is only N2,400"

Head of unit \#4: "when I asked whether they had ever realized a loss, they told me that whatever they generate every year, they always keep a reserve. When the money from their investment is not forthcoming, they fall back on this reserve so that they keep their customers. Because in Nigeria, no matter their cadre, nobody will like to be associated with loss"

This failure to adhere to rules of financing relating to mudarabah may be attributed to the fact that takaful products are provided by a conventional insurer which is accustomed to paying out a fixed return on its conventional products and so extends this system into its takaful products. This would also imply that there may be lapses in the oversight functions of the regulator as indications of payment of a fixed return were clearly indicated in the policy documents of some the providers.

\section{Summary and Recommendations}

This study gave an insight to the level of exposure to and knowledge of Islamic financial laws and principles, of the management of takaful providers in Nigeria. It also provided an analysis of the shari'ah compliance by management regarding the chosen mode of financing of these takaful providers. In essence, the study discovered that knowledge of Islamic financial principles, particularly those relating to takaful, were generally inadequate or inaccurate amongst the majority of those involved with takaful units of the takaful providers in Nigeria. The study also determined that the takaful providers were in one way or the other, failing to comply strictly with the conditions for the validity under Islamic law of their chosen mode of financing.

From the foregoing, recommendations include the following;

i. Appointment to the positions relating to the provision of takaful services should be based on the possession of necessary knowledge, qualifications and/or experience with Islamic financial law. This could be done by either ensuring they have the necessary qualifications before employment or by providing in-depth training.

ii. Regulators must not only enact laws specifying strict compliance with Islamic financial principles in all facets of takaful operations particularly the mode of financing, a supervisory mechanism should also put in place to ensure compliance.

Finally, though this study is limited to the Nigerian takaful industry, future research may extend the same research questions to other jurisdictions where takaful is also provided.

\section{References}

[1] Abdul Rahim, A., Hassan, M. K. \& Lewis, K. M. Islamic Takaful: Business Models, Shari'ah Concerns and Proposed Solutions. Thunderbird International Business Review, Vol. 49(3) 2007, pp. 371396

[2] Al Wosabi,M., nd. Equity Based Financing. Available online at http://staff.uob.edu.bh/files/620922311_files/Equity-basedFiancing.pdf. Sourced on 4/2/2015

[3] Archer, S., AbdelKarim, R. A \& Nienhaus, V.. Business Models in Takaful and Regulatory Implications. In: Archer, S., AbdelKarim, R. A \& Nienhaus, V. [ed]. Takaful Islamic Insurance: Concepts and Regulatory Issues, John Wiley \& Sons [Asia] Pte. Ltd., Singapore, 2009.

[4] Ayub, M. Understanding Islamic Finance. John Wiley \& Sons, England, 2007.

[5] Bakar, M. D. Shari'ah Principles Governing Takaful Models. In: Archer, S., AbdelKarim, R. A \& Nienhaus, V. [ed]. Takaful Islamic Insurance: Concepts and Regulatory Issues, John Wiley \& Sons [Asia] Pte. Ltd., Singapore, 2009.

[6] Bekkin, R.I. Islamic Insurance: National Features and Legal Regulation, Arab Law Quaterly, Vol. 21, No. 2, 2007. pp.109-134

[7] Berg, B. L. Qualitative Research Methods for the Social Sciences [4 ${ }^{\text {th }}$ ed]. Allyn and Bacon, Boston, 2001.

[8] Bhatty, A. Aspects of Business Operations in Different Takaful Models. A paper presented at the Global Islamic Forum, $26^{\text {th }}-29^{\text {th }}$ March, Kuala Lumpur, 2007. 
Proc. of The Fourth Intl. Conf. On Advances in Economics, Management and Social Study - EMS 2015

Copyright (C) Institute of Research Engineers and Doctors, USA .All rights reserved.

ISBN: 978-1-63248-071-2 doi: 10.15224/ 978-1-63248-071-2-36

[9] Boman, K.M., LeCompte, M. D and Goetz, J. P. Ethnographic and Qualitative Research and why it Doesn't Work. American Behavioral Scientist, Vol. 30(1) 1986, pp. 42-57

[10] Chowdhury, M. R., Ghazali, M. F. \& Ibrahim, M. F. Economics of Cash Waqf Management in Malaysia: A Proposed Cash Waqf Model for PRFctitioners and Future Researchers. African Journal of Business Management, 2001.

[11] Cizaka, M. Incorporated Cash Waqfs: Islamic Non-Bank Financial Instruments From The Past To The Future? A Paper Presented at the Waqf Seminar, Labuan, Malaysia, November 4th 2009.

[12] Dusuki, A. W. \& Abdullah, N. I. Takaful: Philosophy, Legitimacy and Operation In: Dar, H.A and Moghul, U. F. [ed] . The Chancellor Guide to the Legal and Shari'ah Aspects of Islamic Finance. Chancellor Publications Limited, London, United Kingdom, 2009.

[13] Gamal, M. A. Islamic Finance: Law, economics and practice, Cambridge University Press, 2006.

[14] Goetz, J. P. \& LeCompte, M. D. Ethnography and Qualitative Design in Educational Research. Aldine, Chicago, 1984.

[15] Handcock \& Gile. Comment: On the Concept of Snowball Sampling. Sociological Methodology 41(1), 2001 p367

[16] Htay. N. N. S. \& Zaharin, H. R. Critical Analysis on the Choice Of Takaful [Islamic Insurance] Operating Models In Malaysia. World Journal of Social Sciences, 2012. vol. 2, no.

[17] Hussain, M. D. Legal Issues in Takaful. In: Archer, S., AbdelKarim, R. A \& Nienhaus, V. [ed]. Takaful Islamic Insurance: Concepts and Regulatory Issues, John Wiley \& Sons [Asia] Pte. Ltd., Singapore, 2009.

[18] Ibrahim, D. \& Ibrahim, H. Revival of Waqf Properties in Malaysia. A paper presented at the $5^{\text {th }}$ Islamic Economics System Conference organized by Faculty Economics and Muamalat, Universiti Sains Islam Malaysia, Berhaya Times Square, Kuala Lumpur, Malaysia, 2013.

[19] Kasim, Z. M.. Takaful: the Islamic way of insurance. Contingencies, January-February,2005. p 33-38

[20] Khaf, M. and Khan, T. Principles of Islamic financing. Research Paper No. 16, Islamic Research and Training Institute. Islamic Development Bank, Jeddah, 1992.

[21] Kwon, W. J. Islamic Principle and Takaful Insurance: Re-Evaluation. Journal of Insurance Regulation, 2007. Vol. 26, issue 1, pp53-81

[22] Maysami, R.C. and Kwon, W.J. An Analysis of Islamic Takaful Insurance: A Cooperative Insurance Mechanism. Journal of Insurance Regulation, 1999

[23] Muhammad, M. T. S., Iman, M., Hamid, A. Obstacles to the Current Concept of Waqf to the Development of Waqf Properties and Recommended Alternative. The Malaysian Journal of Real Estate, 2006, vol. 1, no. 1, pp.27-38

[24] Nadeem, A. Islamic Business Contracts and Microfinance-A Case of Mudarabah MPRF Paper No. 27194, 2010. Available Online at http://mPRF.ub.uni-muenchen.de/27194/

[26] Obaidullah, M.. Islamic Financial Services. Scientific Publishing Centre, King Abdulaziz University, Jeddah, 2005.

[27] Rejda E. G.. Principles of Risk Management and Insurance, eleventh edition, Prentice Hall, United States 2011.

[28] Robson, C. Real World Research: A Resource for Social Scientists and Practitioner Researchers [ $2^{\text {nd }}$ Ed.]. Blackwell Publishing, United Kingdom, 2002.

[29] Salman, S. A., \& Htay, S. N. N.. Introducing Waqf Based Takaful Model in India. Tazkia Islamic Finance and Business Review, 2014, $7[2]$.
[30] Siddiqui, S. H. Islamic Banking: Rationale, Prospects and Challenges. In: Al-Roubaie, A. \& Alvi, S. [Ed]. Islamic Banking and Finance: Critical Concepts in Economics, Routledge, Abingdon, 2010.

[31] Tolefat, A. \& Asutay, M. Takaful Investment Portfolios: A Study of the Composition of Takaful Funds in the GCC and Malaysia. John Wiley and Sons, Singapore, 2013.

[32] Usmani, M. T. An Introduction to Islamic finance. Arham Shamsi, 1998.

About Author (s):

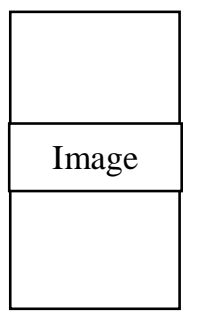

Maryam Dikko is a PhD Fellow in

Universiti Utara, Malaysia specializing in Islamic Insurance.

Abdullah B Hj Abdul Ghani is a

Professor in the Department of Muamalat, Islamic Business School at the College of Business, Universiti Utara, Malaysia. 